\title{
Danube Delta: monitoring and ecological status. A link between the past and the future
}

\author{
CATALINA STOICA* ${ }^{* 1}$, ELENA STANESCU ${ }^{2}$, IULIANA PAUN ${ }^{1}$, ALINA BANCIU ${ }^{1}$, \\ STEFANIA GHEORGHE ${ }^{1}$, IRINA LUCACIU ${ }^{1}$, GABRIELA VASILE ${ }^{1}$, MIHAI NITA-LAZAR ${ }^{1}$ \\ ${ }^{I}$ National Research and Development Institute for Industrial Ecology ECOIND Bucharest, 71-73 Drumul Podul Dambovitei, 060652,
Bucharest, Romania
${ }^{2}$ Research Centre for Ecological Services “Dan Manoleli”, (CESEC), University of Bucharest, 1-3 Aleea Portocalelor, Bucharest,
Romania
"corresponding author (e-mail): catalina.stoica@incdecoind.ro
}

The paper aims a review of the water quality monitoring and evaluation studies conducted at National R\&D Institute for Industrial Ecology over the last ten years, at the level of aquatic ecosystem complexes in the Danube Delta.

The paper will include a broad compendium of data including: a data bank of abiotic variables which control the structure and composition of biotic communities; studies of ecological status assessment; methodology development for assessing the bioaccumulation of chemical pollutants (metals) in the biota; ecotoxicological study of surface water and sediment on aquatic organisms (algae, crustaceans, rotifers); studies on the benthic invertebrate species as biological vectors for pathogens; technical / scientific support for 5 national / international project proposals; 19 papers published in international / national journals; 22 papers presented at international / national scientific conferences.

Keywords: ecological status assessment, Danube Delta, ecotoxicity, bioaccumulation

It is well-known that the aquatic ecosystems (including coastal waters, rivers, lakes) provide numerous ecosystem services, including aquaculture, fisheries, transportation, electricity generation, water supply for agriculture (irrigation), raw water source for drinking and human consumption, exploitation of natural resources (oil, gas) as well as cultural and recreational services [1]. However, the constant increase of the anthropogenic pressure, especially in the last years, have diminished the capacity of aquatic ecosystems to sustain ecological communities. The Water Framework Directive (2000/60 / EC) (WFD) adopted a global sets of measurement to solve the environmental issues and to achieve environmental sustainability in a holistic, integrative way by taking into account the social requirements, too. The WFD preceded the US Clean Water Act in 1979, and a clear correspondence between the two reglementations regarding the objectives, implementation and ecological approach was noted. The WFD purpose was to establish a framework for the implementation of sustainable water management strategies for the long-term protection of water resources. The main objectives were the protection and improvement of the aquatic environment quality to achievement of "good ecological status" for all water bodies by 2015 [2] or at the latest by 2027 [3]. However, after 18 years of implementation, WFD continues to be a major challenge $[4,5,6,7]$. Member States of the European Union have spent considerable resources and time developing the instruments and obtaining the necessary data for the preparation of River Basin Management Plans (RBMP). In addition, WFD has imposed the change of environmental management objectives from the simplistic approach that includes pollution control, to the holistic approach, considering the system integrity as a whole.

Thus, the "backbone" of the ecosystems biomonitoring have been based on the response of biotic communities to stress factors, rather than the variability of the physical-chemical parameters. Nowadays, there is a need to develop rapid, cost-effective tools such as genomic instruments which represent a promising alternative to meet the environmental protection and monitoring goals. Many studies published in the last three years focused on comparability between conventional methods based on morphological identification of biological models and alternative methods of 
DNA metabarcoding. The development of DNA sequencing technologies has been a promising alternative for biodiversity monitoring, especially as these techniques can allow rapid taxonomic identification, high accuracy, costeffective analysis allowing multiple samples to be analyzed simultaneously by contrast with conventional methods, higher costs and time analysis as well as the vast and specific knowledge on groups of organisms (identification and quantification of phytoplankton, phytobenthos and benthic invertebrates) $[8,9]$. The use of specific DNA sequences to identify species can overcome the problems mentioned above. In other words, these alternative methods have the ability to fundamentally change the assessment of the ecological status of freshwater systems worldwide.

In the present paper, the main results of Danube and Danube Delta systems water quality obtained after more than ten years monitoring period were presented.

\section{EXPERIMENTAL PART}

Study area. The monitoring program was developed at spatial (Danube-Danube Delta ecological system) and temporal level (monthly data over ten years' period).

The main sampling sites were selected on the Pontic Ecoregion along Danube: S1) Isaccea

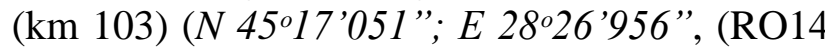
typological category) and Danube Delta (RO15 typological category): S2) Tulcea Upstream (km 82) (N 4511'757”; E 28.47'372”), S3) Tulcea Downstream (km 70) (N 4511'492”; $E$ 28.48'733"); S4) Nufaru (km 101) (N

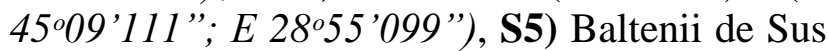
(km 97) (N 4506'752”; E 28.59'212”, S6) Mahmudia (km 90) (N 45०04'685”;
E 29004'749”), S7) Murighiol (km 64) (N 4502'426”; E 2911'090”), S8) Uzlina (km 70) $\left(N 45^{\circ} 04^{\prime} 452^{\prime \prime}\right.$; E 29०13'384"), S9) Ivancea (km

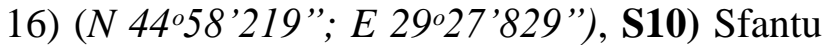
Gheorghe Port (N 44'53'467'; E 29³5'663'), S11) Black Sea Confluence $(\mathrm{km} \quad 0) \quad(N$

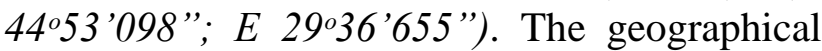
localization of the sampling sites was performed using GPS type system map 60CSx-Garmin (Figure 1).

Data bank. Physico-chemical quality elements such as $\mathrm{pH}$, conductivity, dissolved oxygen (DO), total dissolved solides (TDS), chemical oxygen demand (COD), biochemical oxygen demand (BOD), heavy metals (Fe, Mn, $\mathrm{Zn}, \mathrm{Cd}$, $\mathrm{Cr}, \mathrm{Cu}, \mathrm{Ni}, \mathrm{Pb}, \mathrm{Hg}, \mathrm{As})$, amonium $\left(\mathrm{N}-\mathrm{NH}_{4}\right)$, nitrates $\left(\mathrm{N}-\mathrm{NO}_{3}\right)$, nitrites $\left(\mathrm{N}-\mathrm{NO}_{2}\right)$, total nitrogen $(\mathrm{TN})$, phosphates $\left(\mathrm{P}-\mathrm{PO}_{4}\right)$, total phosphorus (TP), chlorides, sulphates, sulphides, anionic surfactants, calcium, magnesium, sodium, petroleum products, polycyclic aromatic hydrocarbons (PAH) (12 compounds), phenolic compounds, organochlorine pesticides $(\alpha-\mathrm{HCH}$, $\beta-\mathrm{HCH},-\mathrm{HCH}, \quad \gamma-\mathrm{HCH}$, heptaclor, aldrin, dieldrin, endrin, DDT/DDD/DDE), triazine pesticides (atrazin, simazin), ureic pesticides (diuron, isoproturon, monolinuron) were characterized in water samples according to specific EN ISO standard methods. Alongside chemical indicators detected in water samples, numerous parameters such as As, $\mathrm{Cd}, \mathrm{Cr}, \mathrm{Co}$, $\mathrm{Cu}, \mathrm{Hg}, \mathrm{Ni}, \mathrm{Pb}, \mathrm{Zn}, \mathrm{Fe}, \mathrm{Mn}, \mathrm{PAH}(12$ compounds), organochlorine pesticides $(\alpha-\mathrm{HCH}$, $\beta-\mathrm{HCH}, \quad-\mathrm{HCH}, \quad \gamma-\mathrm{HCH}, \quad$ heptaclor, aldrin, dieldrin, endrin, DDT/DDD/DDE), polychlorinated biphenyls (PCBs) and benzene, toluene, ethylbenzene and xylene (BTEX) were characterized in sediment samples. 


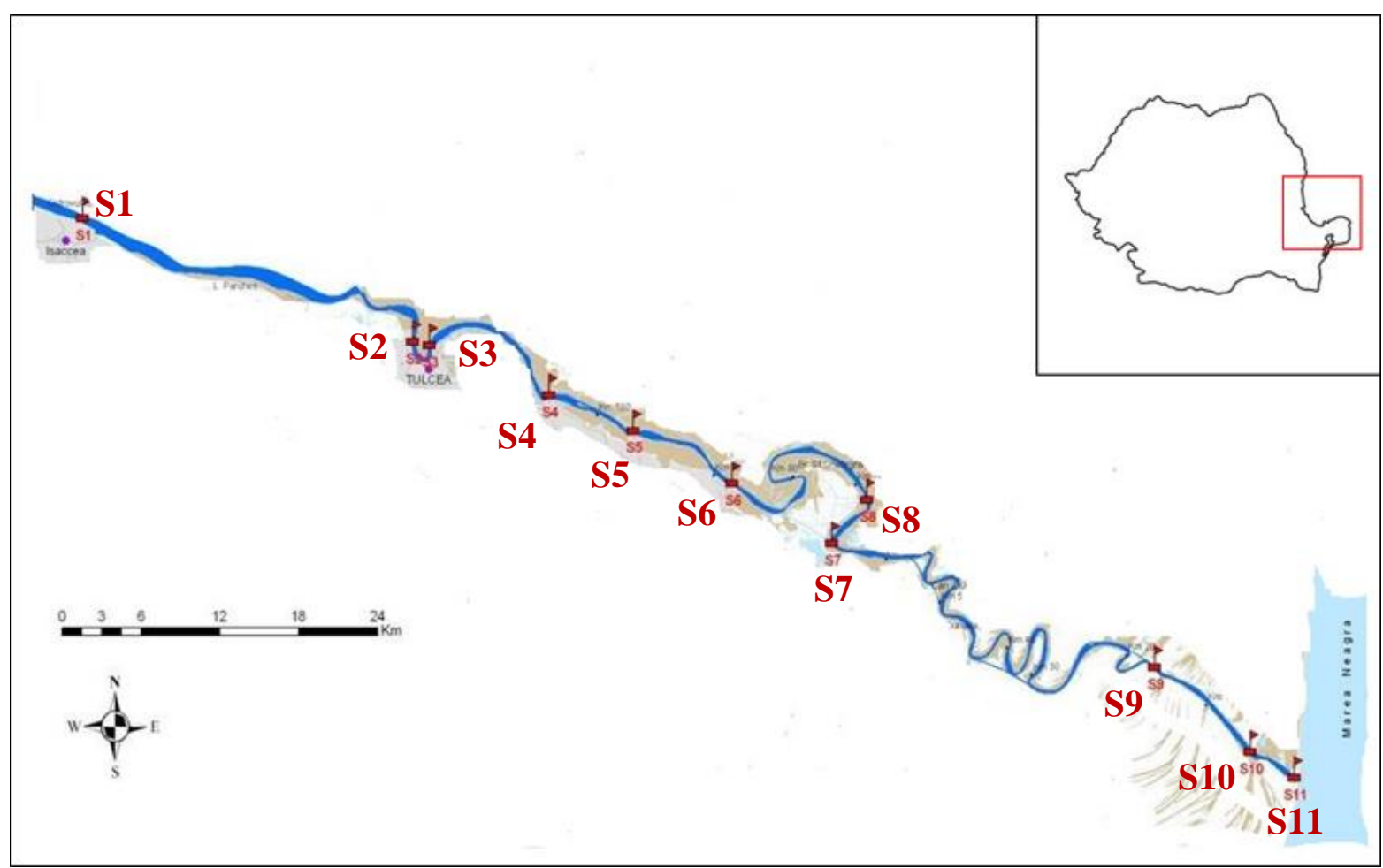

Fig.1. The geographical localization of sampling sites along Danube: (Isaccea (S1) and Danube

Delta: Tulcea Upstream (S2), Tulcea Downstream (S3), Nufaru (S4), Baltenii de Sus (S5), Mahmudia (S6), Murighiol (S7), Uzlina (S8), Ivancea (S9), Sf. Gheorghe Port (S10), Black Sea Confluence (S11)

Biological quality elements such as phytoplankton and bacterioplankton (total and faecal coliforms, streptococci) as well as benthic invertebrates and bacteriobenthos were detected both in water and sediment samples.

Ecological status assessment. Abiotic (temperature, oxygenation, mineralization, acidification, nutrients, pollution with priority / priority hazardous substances) and biotic characteristics (diversity, species presence, numerical abundance / biomass) were considered for assessing the ecological status of Danube and Danube Delta aquatic ecosystems following the WFD and RBMP requirements. Briefly, the ecological status assessment of the studied freshwater systems based on benthic invertebrates' fauna involved the organisms sampling considering the standard methods, the drawing up of the taxonomic groups list, the morphological identification and the abundance estimation. The resulting data were used for various indices calculation (such as Ephemeroptera-Plecoptera-Trichoptera index, Shannon-Wiener diversity index, family number index, Oligochaeta-Chironomidae index, functional groups index, water flow preference index and multimetric index). The indexes values were compared with the reference area values (with little or no anthropic impact or historical data) and the subsequent classification in ecological states (very good, good, moderate, weak, bad).

Ecotoxicological study. The toxicity of water and sediment samples was evaluated using various aquatic organisms such as: algae (Selenastrum capricornutum), crustaceans (Daphnia magna, Heterocypris incongruens) and rotifers (Brachionus calyciflorus).

The ecotoxicological study performed along Danube Delta freshwater samples was done during 2013. The methods used and the tests conditions are described in Table 1.

The Danube Delta freshwater toxicity was classified according to the hazard classification system for natural water described by Persoone et al. (2003) [11]: Class I - no acute hazard, no test did not reveal toxic effect; Class II - slight acute hazard, $20 \% \leq$ effect percentage $<50 \%$, in at least one test; Class III - acute hazard, $50 \% \leq$ effect percentage $<100 \%$, in at least one test; Class IV - high acute hazard, effect percentage $=100 \%$, in at least one test; Class V - very high acute hazard, effect percentage $=100 \%$, in all tests. 
Methodology for assessing the metals bioaccumulation in benthic invertebrates. The bioaccumulation of numerous metals (such as: As, Se, Sb, Cd, Cr, Cu, Co, Fe, Mn, Mg, Ni, Pb and $\mathrm{Zn}$ ) was quantified from two bivales species and one gasteropod species collected during summer and autumn 2013 from S7 and S8. The applied methodology was detailed in Gheorghe et al. (2017) [12].

Benthic invertebrates as biological vectors for pathogens. S6, S7, S8 and S10 sampling sites were selected along Danube Delta for the identification of potential vectors of pahogens in the benthic communities' structure. The samples were collected in May and October of 2015. Benthic invertebrates assemblages (live specimens) were sampled using Van Veen dredge (sampling depth of $10 \mathrm{~cm}$ ).

The samples for microbiological parameters analysis were collected in $1 \mathrm{~L}$ glass bottles (for water) and $400 \mathrm{~g}$ (for sediment). The recipients were properly sterilized at $160^{\circ} \mathrm{C}$. Benthic macroinvertebrates were separated by taxonomic groups using Motic stereomicroscope and identified by specific determination keys. The identification and characterization of microorganisms was carried out on the OmniLog automated system (Biolog Inc., USA).

Table 1. Bioassays used to assess the water and sediment toxicity in Danube Delta (according with

Gheorghe et al. (2016) [10]

\begin{tabular}{|c|c|c|c|c|c|c|}
\hline $\begin{array}{c}\text { Method/ } \\
\text { Microbiotest }\end{array}$ & $\begin{array}{c}\text { Tested } \\
\text { organisms }\end{array}$ & Test type & $\begin{array}{c}\text { Examined } \\
\text { behavior }\end{array}$ & $\begin{array}{l}\text { Test duration/ } \\
\text { temperature }\end{array}$ & $\begin{array}{l}\text { Sample } \\
\text { matrix }\end{array}$ & Treatment \\
\hline $\begin{array}{c}\text { OECD 201 } \\
\text { AlgaltoxKit } \mathrm{F}^{\mathrm{TM}}\end{array}$ & $\begin{array}{c}\text { Selenastrum } \\
\text { capricornutum }\end{array}$ & $\begin{array}{l}\text { Acute / } \\
\text { Chronic }\end{array}$ & $\begin{array}{c}\text { Growth } \\
\text { inhibition }\end{array}$ & $\begin{array}{c}72 \mathrm{~h}, \\
21-25^{\circ} \mathrm{C}\end{array}$ & Water & Undiluted \\
\hline $\begin{array}{c}\text { OECD 202 } \\
\text { DaphtoxKit F }\end{array}$ & Daphnia magna & Acute & Mortality & $24-48 \mathrm{~h}, 20^{\circ} \mathrm{C}$ & Water & Undiluted \\
\hline $\begin{array}{c}\text { ASTM Standard Guide } \\
\text { E1440-91 } \\
\text { RotoxKit } F^{\mathrm{TM}} \\
\end{array}$ & Brachionus calyciflorus & Acute & Mortality & $\begin{array}{l}24 \mathrm{~h}, \\
25^{\circ} \mathrm{C}\end{array}$ & Water & Undiluted \\
\hline $\begin{array}{c}\text { ISO } 14371 \\
\text { OstracodtoxKit } \mathrm{F}^{\mathrm{TM}}\end{array}$ & $\begin{array}{l}\text { Heterocypris } \\
\text { incongruens }\end{array}$ & Chronic & $\begin{array}{l}\text { Mortality } \\
\text { Growth } \\
\text { inhibition }\end{array}$ & $\begin{array}{l}6 \text { days, } \\
25^{\circ} \mathrm{C}\end{array}$ & Sediment & Untreated \\
\hline
\end{tabular}

\section{RESULTS AND DISCUSSIONS}

Data bank. In the last ten years, National R\&D Institute for Industrial Ecology developed various studies aiming to characterize the water quality of Danube Delta systems under an extensive and intensive monitoring program. A large database comprising the monthly values of abiotic variables and the dynamics of biotic communities was established.

The data collected from numerous physicochemical parameters of the water samples, collected along Sfantu Gheorghe Branch, showed a high organic load (expressed as COD and BOD) mainly at S7 during 2003-2013 and a high nutrients concentration $(1.08 \mathrm{mg} / \mathrm{L}$ to 7.72 $\mathrm{mg} / \mathrm{L}$ of total nitrogen and $0.03 \mathrm{mg} / \mathrm{L}$ to 0.48 $\mathrm{mg} / \mathrm{L}$ of total phosphorus) [37].

The increased concentration of COD, BOD and nutrients were due to the conversion of flood zones into agricultural lands associated with the extensive use of fertilizers which occurred in the second half of the $19^{\text {th }}$ century. In the same period of time, the industrialization and the development of socio-economical systems [13] led to the accumulation of a broad range of chemical compounds, an effect which was found worldwide in hydrographic basins, including Danube and Danube Delta systems [14]. For instance, at the level of ecosystem complexes represented by Mahmudia meander, in the last 10 years, there was an over the limit (imposed by the Romanian / European legislation) presence of specific organic pollutants such as: polycyclic aromatic hydrocarbons (benz (a) anthracene, benzo (b) fluorantren, fluorantren, phenanthrene), $\gamma$ - HCH (lindan), heptachlor, DDT / DDE / DDD, polychlorinated biphenyl compounds (PCBs) and petroleum hydrocarbons as well as heavy metals $(\mathrm{Hg})[15,16,17,18,19$, 20].

In spite of an improvement of water quality observed in recent years, the Danube and the Danube Delta (Sfantu Gheorghe Branch) continue to be exposed to numerous point and nonpoint pollution sources [21]

The changes that occurred in the structure, the hydrological regime and the hydrochemistry at 
the level of the ecosystem complexes represented by the Danube and the Danube Delta (Sfantu Gheorghe Branch), were followed by profound changes in the taxonomic composition and distribution of the biocenoses.

The densities of both coliform bacteria and Enterococcous in water samples were high during the summer and autumn sampling campaigns. Moreover, various antibiotic resistant bacteria were identified [22]. However, annual averages of faecal bacteria densities decreased in recent years in Danube Delta, due to the reduction of nutrient concentration $(\mathrm{N}, \mathrm{P})$ $[23,24]$. The qualitative analysis of phytoplankton community along the Danube Delta sampling sites over ten-years study, emphasized the presence of species belonging to the classes Baccilariophyceae, Chlorophyceae, Euglenophyceae and Cyanophycae. In all sampling sites, the oligo-betamezosaprobe, betamezosaprobe, beta-alfamezosaprobe and alfamezosaprobe species dominated. The taxonomic diversity of phytoplankton included 64 species of algae, but the most frequent were Asterionella formosa, Cymatopleura solea, Melosira varians, Navicula gracilis, Cymbella ventricosa, Phacus longicauda, Scenedesmus quadricauda, Pediastrum duplex, Amphipleura pellucida, Fragilaria crotonensis, Nitzschia sigmoidea [25]. The distribution of phytoplankton species was conditioned by the availability of light, dissolved oxygen, nutrients, but also by the dynamics of the hydrological regime. The phytoplankton densities increased from Isaccea (S1) (32.750 ind/L, average numerical density calculated during 2012-2013) located on the Danube downstream to the Sfantu
Gheorghe Branch sites, due to the intake of phytoplankton from lakes and canals. It is the case of S8 (Uzlina) sampling site which recorded the highest numerical densities during 2003-2013 (40.145 ind/L).

The benthic invertebrate fauna was composed of species belonging to Gasteropoda, Bivalvia, Oligochaeta, Insecta, Crustacea taxonomic groups, with greater abundance and diversity in the stations located on Sfantu Gheorghe Branch, compared to those on the Danube likewise phytoplankton communties, but lower compared to those reported by other studies conducted on Danube [26, 27, 28, 29, 30, 31, 32, 33]. This reduction of the taxonomic richness from upstream to downstream was considered to be due to the heterogeneity and size of the particles / sediment granulation, alongside the increase of control factors pressure [34].

The heavy metal profile in the Danube Delta sediment had a specific configuration. The concentration of heavy metals $(\mathrm{Zn}, \mathrm{Hg}, \mathrm{Cu})$ increased until 1989, due to the increase of industrialization in Central and Eastern Europe [35], including in Romania. However, during the last 5 decades a decrease of metals concentration in the Danube Delta was recorded (Table 2).

Although, the concentration of metals in the sediment diminished in the last 10 years between 2 to 5 folds, however, some of them have been adsorbed on the surface of the debris or humic acids. The neglecting of plans regarding intensive agriculture in the Danube Delta, contributed to the reduction of $\mathrm{Cd}$ concentration as this compound is part of fertilizers.

Table 2. Variation of heavy metals (mg/ kg s.u) in the sediments of the Danube Delta during the last five decades

\begin{tabular}{ccccc}
\hline Quality element & U.M & Winkels et al., 1998 [35] & Vosniakos et al., 2010 [18] & $\mathbf{2 0 1 2 - 2 0 1 3}$ \\
\hline $\mathbf{C u}$ & & 38 & $14.8-194$ & $4.65-45.9$ \\
$\mathbf{P b}$ & & 36 & $7.5-51.3$ & $4.76-41.3$ \\
$\mathbf{Z n}$ & mg/kg d.m & 90 & $29.8-218$ & $17.7-93.1$ \\
$\mathbf{C r}$ & & 50 & $7.5-61.9$ & $7.62-32.5$ \\
$\mathbf{N i}$ & & 56 & $19-111$ & $10.8-49.8$ \\
$\mathbf{C d}$ & & $<0.5$ & $<0.5-1.5$ & BDL* \\
\hline
\end{tabular}

*BLD-below detection limit

Decreased $\mathrm{Pb}$ may also be associated with changes in land use, as it also includes fungicides and other pesticides. At the same time, the phasing out of gasoline with $\mathrm{Pb}$ is a complementary method of reducing this contaminant. The increase of metals 
concentration along Danube Delta sampling points was due to the nonpoint contamination from non-ferrous deposits abandoned after the transitions in the Romanian economy [36]. In addition, PAH concentrations increased almost seven-fold compared to concentrations determined in 1950 [35], confirming the negative impact of navigation development (data not shown).

Moreover, the organochlorine pesticides concentration decreased after 1990, with changes in the political sector, but still persist in the sediments of the Danube Delta. A visible decrease between 2012-2013 and 2003-2011, with the exception of DDT and its degradation products was observed [15, 16, 17, 18, 25, 37]. However, there was a positive correlation between the concentrations of the organochlorine pesticides and the benthic indices: Saprobic index (IS), OligochaetaChironomidae $(\mathrm{OCH} / \mathrm{O})$ and Hilsenhoff biotic index (IBH) at S6 (Mahmudia), S7 (Murighiol), S9 (Ivancea) and S10 (Sf. Gheorghe) in terms of increase values of the indices due to the increased values of organochlorine pesticides (data not shown).

As a result, the structure and composition of the benthic communities changed, by reducing the number of taxonomic groups, the replacing of sensitive sepcies with the tolerant ones, often invasive as well as the replacing of shredders or collectors with detritivores (data not shown).

Studies conducted after 1990 have shown a pronounced simplification of biocenoses integrated into aquatic systems [38,39,25], preceding a period of restoration of the structure and composition of the benthic invertebrate fauna [40].

Overall, a general tendency of benthic fauna recovery in terms of taxonomic richness was observed during the monitoring period at the level of ecosystem complexes in the Danube and Danube Delta (data not shown).

A large database was created based on the monitoring of Danube Delta water quality over ten years' period (2003-2013) and subsequently, it was possible to perform a comprehensive study of Danube Delta ecological status assessment. The macroinvertebrates' community composition was used as they are closely related to habitat and substrate heterogeneity. Moreover, 'biological quality elements' were more affected by anthropic and environmental pressure factors rather than 'chemical quality elements' [41].

\section{Ecological status assessment.}

Characterization of the state variables (both chemical and biological quality elements) that influence the composition and structure of macroinvertebrates organisms, as well as the dynamics of these biological elements, allowed the assessment of the ecological status of the Danube and Danube Delta. Therefore, taking into account the "worst case" principle and the results obtained during 2012-2013 from both biological and chemical quality elements, the assessment induced ,good" ecological status for Danube system (typological category RO14) and "moderate" ecological status for Danube Delta (typological category RO15) (data not shown). The assessment of freshwater systems ecological status was completed by an in-vitro ecotoxicological study.

Ecotoxicological study. Primary producers (algae, Selenastrum capricornutum) and consumers (planktonic crustaceans, Daphnia magna and rotifers, Brachyonus calyciflourus as well as benthic crustaceans (Heterocypris incongruens) were used to evaluate the Danube Delta water and sediment quality according to hazard classification system of natural water [11]. The water samples showed no acute toxic effect (Class I) or slightly acute toxic effect (Class II). The sediment samples were more toxic than water samples due to the pollutants accumulation (e.g metals, PAH, organochlorine pesticides). Their main toxicity classes were from Class II - slightly acute toxic effect and Class III - acute toxic effect up to Class IV high acute toxicity. The largest number of water toxic responses was observed in case of Selenastrum capricornutum algae, followed by Daphnia magna crustaceans and Brachyonus calyciflourus rotifers. In case of sediment, the highest number of toxic responses were obtained from Heterocypris incrongruens ostracods [10]. In addition to the development of the database comprising a large number of water quality indicators, the study of freshwater systems ecological status assessment as well as an ecotoxicological study, a methodology for the evaluation of metals bioaccumulation in biota was implemented. 
Methodology for assessing the metals bioaccumulation in benthic invertebrates. The researches that founded the above mentioned methodology was carried out in 2013 (July and September) along Danube Delta (S7, S8 and S10) regarding the accumulation of chemical pollutants (metals) in Mollusks (two Bivalve species: Anodonta sp., Unio sp. and one Gasteropode: Viviparus sp.) [42].

The results pointed out that the metals involved in the metabolic processes ( $\mathrm{Fe}, \mathrm{Mn}, \mathrm{Zn}, \mathrm{Cu}$ and $\mathrm{Mg}$ ) have a greater accumulation capacity than the toxic ones $(\mathrm{Pb}$ and $\mathrm{Cd})$. This fact was also explained by the presence of these metals in high concentrations, reported in previous studies [43]. Moreover, Vasile et al. (2006, 2005) [20, 44] observed that $\mathrm{Pb}$ was either mobile or bound to manganese oxides and organic matter in sediment samples. The mobile $\mathrm{Pb}$ concentration was higher in the sediment at S7 due to the increase of the total concentration of metals in the sediment, compared to the concentration of metals detected at S8, where a decrease concentration in the mobile form for $\mathrm{Cu}, \mathrm{Zn}$ and $\mathrm{Pb}$ was detected in 2004, compared to 2003.

Furthermore, Vosniakos et al. (2010) [18] showed that the mobile fraction $(1.2-3.1 \mathrm{mg} /$ $\mathrm{kg}$ ) of $\mathrm{Cu}$ represents $41 \%$, and $\mathrm{Ni}$ showed a relatively low mobility compared to its total concentration.

Gheorghe et al (in tech) highlithed that the bioaccumulation level fluctuated considering the species, metals type, and sampling sites. A greater difference of bioaccumulative metals impact ( $\mathrm{Ni}$ and $\mathrm{Zn}$ ) at $\mathrm{S} 7$ compared to $\mathrm{S} 8$ was observed. The study of metal bioaccumulation capacity in the mollusks shell from Danube Delta aquatic system underlined that metals involved in metabolic processes (such as $\mathrm{Fe}$, $\mathrm{Mn}, \mathrm{Zn}, \mathrm{Cu}$, and $\mathrm{Mg}$ ) had a greater storage capacity than the toxic ones (such as $\mathrm{Pb}$ and $\mathrm{Cd}$ ) [12]. The selectivity of the metal bioaccumulation was represented as follows: $\mathrm{Fe}>\mathrm{Mn}>\mathrm{Zn}>\mathrm{Cu}>\mathrm{Pb}>\mathrm{Co}>\mathrm{Cd}$, in case of Viviparus sp. shell, while the shell of Anodonta $s p$. had a higher accumulation capacity of metals $(\mathrm{Cu}, \mathrm{As}, \mathrm{Cr}, \mathrm{Zn}$ ) compared to Unio sp. (data not shown). Overall, bioaccumulation factors were subunitary, which indicated a slowly bioaccumulation process along Danube Delta. Since, the macroinvertebrates represent the key component of aquatic ecosystems, the group was largely examined in our over ten-years studies. A number of functions performed by benthic invertebrates' fauna have been mainly related to trophic relations (accumulating, transforming and transferring the stored energy from organic detritus decomposition and nutrient transfer to the higher trophic levels, information circulation and systems self-regulation $[45,46,47,48]$. The advantage of using benthic invertebrates' fauna in the freswater quality evaluation studies was due to their ability to maintain in their structure the effects of environmental pressure [49, 40].

Moreover, the invertebrates have relatively long life and widespread distribution, limited mobility and they cannot avoid adverse conditions when exposed to environmental issues (such as eutrophication, acidification, low oxygen concentrations, hydromorphological changes or other problems combined with habitat loss (e.g. embankments, etc.).

Thus, the benthic communities were considered suitable for either the bioaccumulation of specific toxic pollutants in their structure, or characterization and assessment of ecological status of aquatic ecosystems quality, including the identification of various benthic taxonomic groups as vector for pathogens.

Benthic invertebrates as biological vectors for pathogens. The identification of potential pathogen vectors of the benthic communities' structure was carried out in S6, S7, S8 and S10 sampling sites along Danube Delta. The samples were collected in May and October of 2015.

The results pointed out that alongside the structure of benthic invertebrate fauna (potential vectors for pathogens) from the ecological system of the Danube Delta, a wide range of stable endogenous bacteria were identified. Since the frequency of occurrence reported in 2014 was greater than 50\% (Figure 2) [40], several benthic invertebrates' groups were used as sentinels to assess the prevalence of pathogens microorganisms, such as: filters (Dreissena polymorpha, Anodonta cygnea, Unio pictorum), scrapers (Viviparus acerosus, Esperiana esperi, Esperiana acicularis, Lithoglyphus naticoides, Theodoxus danubialis and Chironomidae) and detritivores (Oligochaeta, Ceratopogonidae). 


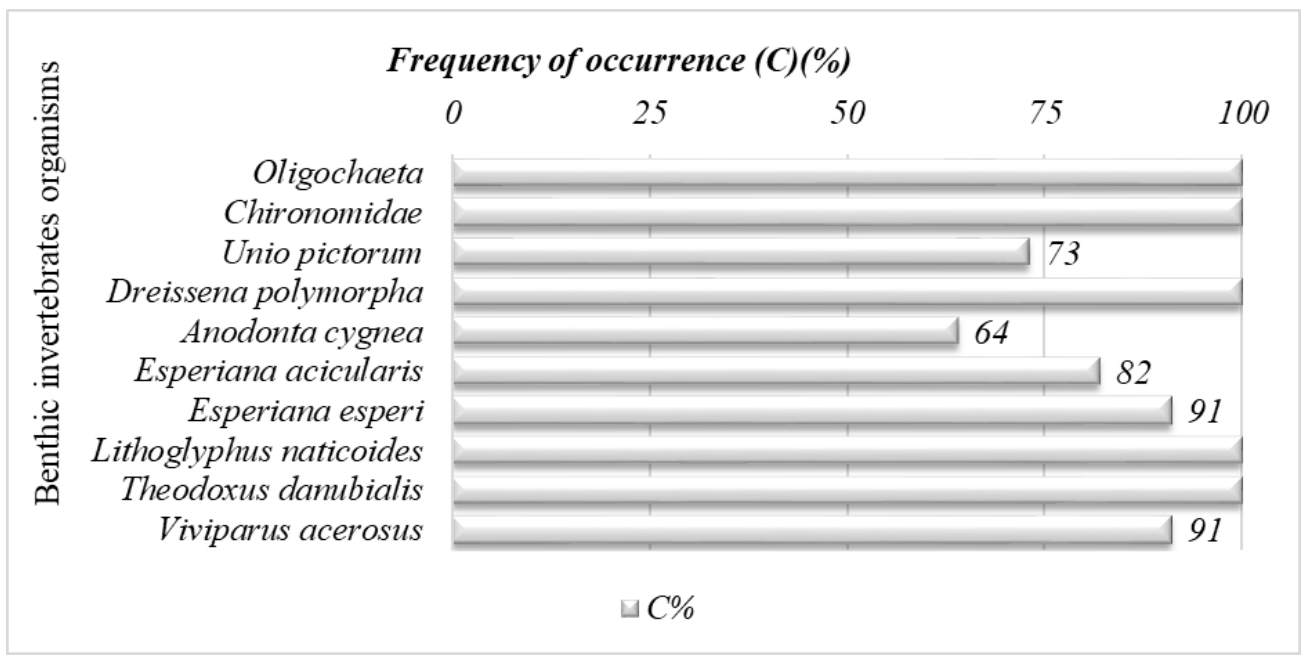

Fig. 2. Frequency of occurrence of benthic invertebrates

Although 15 pathogen species were detected in all sampling sites subjected to untreated wastewater discharges, mainly linked with animal and human fecal waste, Citrobacter freundii and Raoultella plancticola / ornithinolytica were the most common bacteria species, especially associated with Diptera larvae and Mollusks species.

\section{CONCLUSIONS}

The paper presented a summary of all the studies carried out in the National R\&D Institute for Industrial Ecology for more than 10 years at the level of aquatic ecosystems complexes of Danube and Danube Delta, considering the anthropogenic pressure after the industrialization period. The studies aimed to highlight the ecological integrity of aquatic systems considering both chemical and biological components monitoring. The main issues that Danube and Danube Delta still facing are: high organic load (expressed COD and BOD), pathogenic microbial load as well as, the increase of antibiotic bacterial resistance, high concentrations of heavy metals (copper, nickel, zinc, mercury), organochlorine pesticides (lindane, DDT/DDE/DDDs), PAHs and PCBs, mosly detected in sediment. A reduction of sensitive benthic invertebrates' species and replacing with the tolerant ones was observed.
Moreover, benthic invertebrates' fauna was strongly related with pathogens and can be further used as alternative monitoring systems for waterborne contamination. In addition, since the Danube Delta water body was framed in 2013 as „moderate” ecological status according with WFD, alternative methods needs to be tested in order to meet the good ecological status by 2027 .

Future recommendations. Since the good ecological status for all water bodies by 2015 was not achieved, alternative methods needs to be tested to meet this criterion by 2027 . Several steps further were made at international level [50] by means of DNA metabarcoding identification of prokaryotic and eukaryotic organisms, yet certain "methodological limitations" [51] have been identified, namely: a) biomass estimation [52]; b) detection of rare species [53]; c) incomplete reference libraries $[54,4]$.

Considering those issues, our future studies will focus on the application of alternative methods at national level, which may contribute to the identification of functional diversity based on gene expression (transcription), and thus, to meet a WFD target that could not be adequately covered based on conventional morphological identification methods.

ACKNOWLEDGEMENTS. This work was financially supported by the National Core Program within several contracts: 20N/2019, Project no. PN 19-04 02 01, 13N/2009, Projects no. 09-1302 03, PN 09-13 02 14, 12N/2006, Project no. PN 06-12 0113. 


\section{REFERENCES}

1. CORDIER, T., LANZEN, A., APOTHELOZ-PERET-GENTIL, L., STOECK, T., PAWLOWSKI, J., 2019, Trends in Microbiol., 27, nr. 5, p. 387-397.

2. EC, 2000, Directive 2000/60/EC of the European Parliament and of the Council of 23 October 2000 establishing a framework for the Community action in the field of water policy, Off J, L 327, p. 1-72.

3. POIKANE, S., ZAMPOUKAS, N., BORJA, A., DAVIES, S.P., VAN DE BUND, W., BIRK, S., Environ. Sci. Policy, 44, 2014, p. 237-246.

4. HERING, D., BORJA, A., JONES, I., PONT, D., BOETS, P., BOUCHEZ, A., BRUCE K, DRAKARE, S., HANFLING, B., KAHLERT, M., LEESE, F., MEISSNER, K., MERGEN, P., REYJOL, Y., SEGURADO, P., VOGLER, A., KELLY, M., Water Res., 138, 2018, p. 192-205.

5. HERING, D., BORJA, A., CARSTENSEN, J., LAURENCE, C., ELLIOTT, M., FELD, C.K., HEISKANEN, A.S., JOHNSON, R.K., MOE, J., PONT, D., SOLHEIM, A.L., VAN DE BUND, W., Sci. Total Environ., 408, 2010, p. 4007-4019.

6. VOULVOULIS, N., ARPON, K.D., GIAKOUMIS, T., Sci. Total Environ., 2017, 575, p. 358-366

7. MOldoveanu, M., RISNOVEANU, G., Conferinta Stiintifica Jubiliara a Institutului National de Hidrologie si Gospodarire a Apelor, 28-30 septembrie 2010, Bucuresti (in Romanian).

8. LOBO, J., SHOKRALLA, S., COSTA, M.H., HAJIBABEI, M., COSTA, F.O., Sci. Rep., 7, 2017, p. 15618

9. SERRANA, J, MIYAKE, Y., GAMBOA, M., WATANABE, K., Ecol. Indic., 101, 2019, p. 963-972.

10. GHEORGHE, S., STOICA, C., PAUN, I., LUCACIU, I., NITA-LAZAR, M., CRISTOFOR, S., J. Environ. Prot. Ecol., 17, no. 1, 2016, p. 171-181.

11. PERSOONE, G., et al., Environ. Toxicol., 18, no. 6, 2003, p. 395.

12. GHEORGHE, S., STOICA, C., VASILE, G.G., NITA-LAZAR, M., STANESCU, E., LUCACIU, I., Metals toxic effects in aquatic ecosystems: modulators of water quality, 4, In: Water Quality, InTech, Hlanganani Tutu (Ed.), ISBN 978-953-51-2882-3, DOI: 10.5772/65744, 2017.

13. ZALASIEWICZ, J., WILlIAMS, M., STEFFEN, W., CRUTZEN, P., Env. Sci. \& Tech., 44, 2010, p. 2228-2231.

14. KELLER, E., BARBARA, M., LATHJA, K., CRISTOFOR, S., Wetlands, 18, no. 1: 1998, p. $42-50$.

15. PETRE, J., CRUCERU, L., NICOLAU, M., VASILE, G., MITRITA, M., IANCU, V., Rev. Chim. (Bucharest), 55, no. 4, 2004, p. 264-268.

16. VOSNIAKOS F, PETRE, J., VASILE, G.G., CRUCERU, L., NICOLAU, M., MITRITA, M., IANCU, V., CRUCERU, I., Fresenius Environ. Bull., 15, no.5, 2006, p. 401-408

17. VOSNIAKOS, F., VASILE, G., PETRE, J., CRUCERU, L., NICOLAU, M., MITRITA, M., IANCU, V., CRUCERU, I., Fresenius Environ. Bull., 17, 1, 2008, p. 372-389

18. VOSNIAKOS, F., PETRE, J., PASCU, L.F., VASILE, G., IANCU, V., STANILOAE, D., NICOLAU, M., CRUCERU, L., GOLUMBEANU, M., Fresenius Environ. Bull., 19, no. 1, 2010, p. 20-29.

19. VASile, G., PETRE, J., CRUCERU, L., NiCOlAU, M., MitRITA, M., IANCU, V., VOSNIAKOS, F., J. Environ. Prot. Ecol., 8, no. 4, 2007, p. 739-747.

20. VASILE, G., CRUCERU, L., PETRE, J., J. Environ. Prot. Ecol., 7, no. 2, 2006, p. 293-300.

21. LISKA, L., WAGNER, F., SLOBODNIK, J., Joint Danube Survey - Final Report ICPDR International Commission for the Protection of the Danube River, 2008, p. 235.

22. BANCIU (CATRANGIU), A., NICULESCU, D., NITA-LAZAR, M., LUCACIU, I., STOICA, C., MIHAESCU, G., J. Environ. Prot. Ecol., 17, no. 1, 2016, p. 127-135. 
23. KIRSCHNER, A.K., KAVKA, G.G., VELIMIROV B., MACH, R.L., SOMMER, R., FARNLEITNER, A. H., 2009, Water Res., 43, p. 3673-3684.

24. PALL, E., NICULAE, M., KISS, T., SANDRU, C.D., J. Med. Microbiol., 62, no. 11, 2013, 1635-1640.

25. STANESCU, E., STOICA, C., VASILE, G., PETRE, J., GHEORGHE, S., PAUN, I., LUCACIU, I., NICOLAU, M., VOSNIAKOS, F., VOSNIAKOS, K., GOLUMBEANU, M., Environmental Security Assessment and Management of Obsolete Pesticides in South-East Europe, NATO Science for Peace and Security Series C: Environment Security, L.I. Simeonov, F.Z. Macaev, B.G. Simeonova (Eds), Springer Science+Business Media Dordrecht, 21, 2013, p. 229-248.

26. GRAF, W., LEITNER, P., PLETTERBAUER, F., The Danube River Basin, The Handbook of Environmental Chemistry, Liska (Ed.), Springer-Verlag Berlin, Heidelberg, 2015.

27. BODIS, E., TOTHA, B., SZEKERES, J., BORZA, P., SOUSA, R., Limnologica, 49, 2014, p.1-9.

28. CSANYI, B., IHTIMANSKA, M., PAUNOVIC, M., PODANI, J., SZEKERES, J., Proposed section typology of the Danube River based on macroinvertebrates collected by different sampling methods, 40 th IAD Conference, 2014.

29. LISKA, L., WAGNER, F., SLOBODNIK, J., 2008, Joint Danube Survey - Final Report ICPDR - International Commission for the Protection of the Danube River, p. 235

30. OERTEL, N., NOSEK, J.N, Proc. 36th International Conference of IAD, 2006, p. 275-279.

31. OERTEL, N., NOSEK, J.N., Internat. Assoc. Danube Res., 2006, p. 36.

32. BERTHOLD, E., KAISER, I., Lauterbornia, 50, 2005, p. 15-17.

33. BERNERTH, H., STEIN, S., Lauterbornia, 48, 2003, 57-60.

34. SOMMERWERK, N., HEIN, T., SCHNEIDER-JACOBY, M., BAUMGARTNER, C., OSTOJIC, A., SIBER, R., BLOESCH, J., PAUNOVIC, M., TOCKNER, K., Rivers of Europe, K. Trockner, C.T. Robsinson, U. Uehlinger (Eds.), London, Burlington (MA), San Diego (CA): Academic Press, 2009, p. 59-112.

35. WINKELS, H.J., KROONENBERG, S.B., LYCHAGIN, M.Y., MARIN, G., RUSAKOV, G.V, KASIMOV, N.S., Appl. Geochem., 13, no. 5, 1998, p. 581-591.

36. VIGNATI, D.A.L., SECRIERU, D., BAGATOVA, Y.I., DOMINIK, J., CEREGHINO, R., BERLINSKY, N.A., OAIE, G., SZOBOTKA, S., STANICA, A., 2013, J. Environ. Manage., 125, p. 169-178.

37. StOICA, C., GHEORGHE, S., PAUN, I., STANESCU, E., DINU, C., PETRE, J., LUCACIU, I., Romaqua, 1, no. 91, 2014, p. 14-20.

38. RISNOVEANU, G., IGNAT, G., Analele Stiinţifice ale Institutului de Cercetare Dezvoltare Delta Dunarii, 1993, p. 177-184 (in Romanian).

39. IGNAT, G., VADINEANU, A., CRISTOFOR, S., NAFORNIŢA, G., RISNOVEANU, G., CIUBUC, C., DINU, C., FlORESCU, C., CRAIOVEANU, M., Analele Stiintifice ale Institutului Delta Dunarii, Tulcea, 1993, p. 87-94 (in Romanian).

40. STOICA, C., GHEORGHE, S., PETRE, J., LUCACIU I., NITA-LAZAR, M., Environ. Eng. Manage. J., 13, no. 9, 2014, p. 2243-2252.

41. STOICA, C., CAMEJO, J., BANCIU, A., NITA-LAZAR, M., PAUN, I., CRISTOFOR, S., PACHECO, O.R., LOPEZ, M.G., Water Sci. Technol., 73, no. 10, 2016, p. 2413-2421.

42. STOICA, C., GHEORGHE, S., LUCACIU, I., STANESCU, E., PAUN, I., NICULESCU, D., Soil Sediment Contam., 23, 2014, p. 1-16,

43. VASILE, G., TANASE, I.G., DINU, C., 2010, Anal. Lett., 43, p. 1199-1206.

44. VASILE, G., CRUCERU, L., NICOLAU, M., PETRE, J., IANCU, V., Rev. Chim. (Bucharest), 56, no 8, 2005.

45. COVICH, A.P., PALMER, M.A., CROWL, T.A., BioScience, 49, no. 2, 1999, p. 119-127.

46. COVICH, A.P., AUSTEN, M.C., BARLOCHER F., CHAUVET, E., CARDINALE, B.J., BILES, C.L., INCHAUSTI, P., DANGLES, O., SOLAN, M., GESSNER, M.O., STATZNER, B, MOSS, B., 54, no. 8, 2004, p. 767-775. 
47. REISS, H., KRONCKE, I., Mar. Pollut. Bull., 50, no. 12, 2005, p. 1490-1499.

48. RISNOVEANU, G., CRISTOFOR, S., ADAMESCU, M., CAZACU, C., IGNAT, G., PARPALA, L., NAVODARU, I., MOLDOVEANU, M., TOROK, L., IONICA, D., ZINEVICI, V., TUDOR, M., PREDA, E., IBRAM, O., VADINEANU, A., Volumul Programului Cercetare de Excelenta 2005 - 2008, MENER energie, Editura Universitatii Politehnica, 2008, p. 238-247.

49. POP, O.G, GRUIA, R., MARCULESCU, A., Environ. Eng. Manage. J., 9, 2010, p. 15931599.

50. ELBRECHT, V., VAMOS, E.E., MEISSNER, K., AROVIITA, J., LEESE, F., Methods Ecol. Evol., 8, no. 10, 2017, p. 1265-1275.

51. MAJANEVA, M., DISERUD, O., EAGLE, S., HAJIBABEI, M, EKREM, T., Metabarcoding \&Metagenomics 2: e26664, 2018.

52. ELBRECHT, V., LEESE, F., PloS one10: e0130324,_2015.

53. LERAY, M., KNOWLTON, N., PeerJ 5: e3006, 2017.

54. HAJIBABAEI, M., BAIRD, D.J., FAHNER, N.A., BEIKO, R., GOLDING, G.B., Philos. Trans. R. Soc. Lond. B. Biol. Sci. 371, no. 1702, 2016, 20150330. 